УДК 336.7

Борисюк Олена,

кандидат економічних наук, доцент,

Волинський національний університет імені Лесі Українки,

кафедра фінансів;

м. Луцьк; ORCID ID 0000-0002-9411-4118

e-mail: lena-borysuk@ukr.net

Шматковська Тетяна, кандидат економічних наук, доцент, Волинський національний університет імені Лесі Українки, кафедра обліку і оподаткування; м. Луцьк; ORCID ID 0000-0003-2771-9982 e-mail: Shmatkovska2016@gmail.com

Дацюк-Томчук Марія, кандидат економічних наук, доцент, Луцький інститут розвитку людини Університету "Україна", кафедра права та фінансів,

м. Луцьк; ORCID ID 0000-0002-9794-8943 e-mail: mashaprof@ukr.net

https://doi.org/10.29038/2786-4618-2021-03-44-53

\title{
ДРАЙВЕРИ ТА БАР'СРИ РОЗВИТКУ ФІНТЕХ НА ФІНАНСОВОМУ РИНКУ
}

Нові технології (цифрові, телекомунікаційні, біометричні) перебудовують індустрію фінансових послуг, активно витісняючи традиційних гравців і традиційні бізнес-моделі. Інтеграція нових фінансових рішень дозволяє змінювати структуру споживання, скорочувати витрати на певний функціонал (обробка клієнтських баз, програми лояльності та ін.), підвищувати ефективність і якість бізнес-процесів (таргетування цільової аудиторії, скоринг та ін.), а також істотно впливати на стійкість розвитку профільного бізнесу та т.д. В результаті індустрія фінансових технологій (або Фінтех) поступово перетворюється в самостійний та інтенсивний сектор.

У статті розглянуто визначення поняття «Фінтех» в зарубіжній і вітчизняній науковій літературі. Разом із тим, систематизовано глобальні напрями Фінтех в Україні та визначено найбільші інвестиційні угоди в сфері Фінтех в 2020 році.

Ключові слова: Фінтех, фінтех компанії; інновації; банки; фінтех-стартапи, загрози, фінансовий ринок.

Борисюк Елена, кандидат экономических наук, доцент, Волынский национальный университет имени Леси Украинки, кафедра финансов, г. Луцк

Шматковская Татьяна, кандидат экономических наук, доцент, Волынский национальный университет имени Леси Украинки, кафедра учета и налогообложения, г. Луцк

Дацюк-Томчук Мария, кандидат экономических наук, доцент, Луцкий институт развития человека университета "Украина", кафедра права и финансов,

$$
\text { г. Луцк }
$$

\section{ДРАЙВЕРЫ И БАРЬЕРЫ РАЗВИТИЯ ФИНТЕХ НА ФИНАНСОВОМ РЫНКЕ}


Новые технологии (цифровые, телекоммуникационные, биометрические) перестраивают индустрию финансовых услуг, активно вытесняя традиционных игроков и традиционные бизнес-модели. Интеграция новых финансовых решений позволяет менять структуру потребления, сокращать расходы на определенный функционал (обработка клиентских баз, программы лояльности и др.), Повышать эффективность и качество бизнес-процессов (таргетирование целевой аудитории, скоринг и др.), а также существенно влиять на устойчивость развития профильного бизнеса и т. д. в результате индустрия финансовых технологий (или Финтех) постепенно превращается в самостоятельный интенсивно развивается сектор.

В статье рассмотрены определение понятия «Финтех» в зарубежной и отечественной научной литературе. Вместе с тем, систематизированы глобальные направления Финтех в Украине и определены крупнейшие инвестиционные соглашения в сфере Финтех в 2020 году.

Ключевые слова: Финтех, Финтех компании; инновации; банки; Финтех-стартапы, угрозы, финансовый рынок.

\author{
Borysiuk Olena, \\ Candidate of Economic Sciences, Associate Professor, \\ Lesya Ukrainka Volyn National University, \\ Department of Finance, \\ Lutsk city \\ Shmatkovska Tetiana, \\ Candidate of Economic Sciences, Associate Professor, \\ Lesya Ukrainka Volyn National University, \\ Department of Accounting and Taxation, \\ Lutsk city
}

\author{
Datsyuk-Tomchuk Maria, \\ Candidate of Economic Sciences, Associate Professor, \\ Lutsk Institute of Human Development, University "Ukraine", \\ Department of Law and Finance, \\ Lutsk city
}

\title{
DRIVERS AND BARRIERS OF FINTECH DEVELOPMENT IN THE FINANCIAL MARKET
}

Today, new technologies (digital, telecommunications, biometric) are restructuring the financial services industry, actively displacing traditional players and traditional business models. Integration of new financial solutions allows to change the structure of consumption, reduce the cost of certain functionality (processing customer bases, loyalty programs, etc.), increase the efficiency and quality of business processes (target audience targeting, scoring, etc.), and significantly affect sustainability development of core business, etc. As a result, the financial technology industry (or Fintech) is gradually becoming an independent intensively developing sector.

The article considers the definition of "Fintech" in foreign and domestic scientific literature. At the same time, the global directions of Fintech in Ukraine are systematized and the largest investment agreements in the field of Fintech in 2020 are determined.

The financial market has undergone drastic changes over the last decade. During this time, it has transformed from a model of traditional corporate business to entire ecosystems of the banking and non-banking markets. Transformations are also dictated by new challenges that stimulate the active growth of digital operations and shape the demand for digital products and services in the financial sector.

Thus, for a long time, banks have been growing due to the offer of traditional relevant products. For example, customers with current accounts were offered credit cards, personal credit lines, home loans, and so on. Later, under the influence of changing customer needs and technology development, banks began to offer related products, going beyond corporate business. Namely, they offered account management, factoring, accounting services, liquidity analysis for small and medium-sized businesses (Idea Bank, ING).

At the same time, Fintech startups began launching mobile account management applications (Moven). Some financial institutions went further in non-banking offerings, providing mobile services (Post Bank), and some cooperated with health care providers and health insurance companies, providing customers with platforms with 
convenient payment for medical services.

By expanding the boundaries of business, traditional players have begun to form value partnerships in related industries, creating ecosystems with additional benefits for customers. Partnership with fintechs and digital giants (bigtech) within the creation of such ecosystems has opened up new opportunities for traditional businesses, customers and fintech technicians themselves. With such rapid development of Fintech in the financial market, it is important to explore the main drivers and barriers to the growth of the Fintech industry in the world.

Key words: Fintech, fintech company; innovations; banks; fintech startups, threats, financial market.

Постановка проблеми. Фінансовий ринок зазнав кардинальних змін упродовж останнього десятиріччя. За цей час він трансформувався з моделі традиційного корпоративного бізнесу до цілих екосистем банківського та небанківського ринків. Трансформації продиктовані й новими викликами, що стимулюють активне зростання діджитал-операцій та формують попит на цифрові продукти $\mathrm{i}$ сервіси у фінансовій сфері.

Так, упродовж тривалого часу банки зростали завдяки пропозиціям традиційних релевантних продуктів. Наприклад, клієнтам 3 поточними рахунками пропонувались кредитні картки, персональні кредитні лінії, позики на купівлю житла, тощо. Згодом, під впливом змін потреб клієнтів та розвитку технологій, банки почали пропонувати суміжні продукти, виходячи за межі корпоративного бізнесу. А саме - пропонували управління рахунками, факторинг, бухгалтерські послуги, аналіз руху ліквідності для малого та середнього бізнесу (Idea Bank, ING).

Розширюючи межі бізнесу, традиційні гравці почали формувати ціннісні партнерства в суміжних індустріях, створюючи екосистеми з додатковими перевагами для клієнтів. Партнерство 3 фінтехами та цифровими гігантами (бігтек) в межах створення таких екосистем відкрило нові можливості як для традиційного бізнесу, клієнтів, так і для самих фінтехів. В умовах такого стрімкого розвитку Фінтех на фінансовому ринку важливо дослідити основні драйвери і бар'єри зростання Фінтех-індустрії в світі.

Аналіз останніх досліджень і публікацій. Результати наукових досліджень у сфері фінансових інновацій наведені у працях таких зарубіжних учених, як Г. Андерсон, Я. Барберіс, Р. Браун, А. Броддас, А.Валлас, М. Вебер, М. Долат, Г. Дорфлайтнер, Р. Леков, Р. Мертон, М. Флеурі, Л. Хорнуф, Д. Хе, В. Хаксар, Д. Хе, А.Херболт, Л. Хорнуф, Дж.Хорслі, С. Чишті, Г. Швабе, М. Шмітт. До вітчизняних науковців, які займаються дослідженням різних аспектів фінансових технологій (FinTech), належать C. В. Волосович, Д. В. Гордєєва, Л. А. Дудинець, Л. В. Жердецька, Л. Г. Кльоба, В. В. Коваленко, А. А. Мазаракі, Н. М. Пантєлєєва, С. І. Паперник, 3. М. Руденко, А. В. Рябова, А. Ю. Семеног, Д. Е. Третьяков, М. С. Яценко. 3 огляду на те, що для індустрії FinTech в Україні характерним є збільшення оборотів і масштабів діяльності, $є$ необхідність в систематизації сутності Фінтех та визначення загроз його розвитку на вітчизняному фінансовому ринку.

Мета і завдання статті. Дослідити сутність та основні поточні тренди розвитку Фінтех на фінансовому ринку.

Виклад основного матеріалу та обгрунтування отриманих результатів дослідження.

Фінансові технології, або Фінтех (англ. "FinTech") - галузь, що складається 3 компаній, що використовують технології та інновації, щоб конкурувати 3 традиційними фінансовими організаціями в особі банків і посередників на фінансовому ринку. В свою чергу Фінтех - це симбіоз фінансів і нових технологій 3 використанням мобільних додатків, i алгоритмів. 3 урахуванням зростання в молодого покоління зацікавленості в фінансах та інвестиціях, процес їх взаємодії через мобільні пристрої полегшується саме через Фінтех. Досить часто Фінтех називають стартапи, які використовують проривні, нові технології в сфері мобільних платежів, переказу грошових коштів, кредитування, залучення капіталу, тощо. Водночас Фінтех надзвичайно швидко змінюється під впливом різних соціальних потреб, що є причиною неоднозначності щодо розуміння даного поняття.

Огляд зарубіжної та вітчизняної наукової літератури показав відсутність єдиної точки зору щодо змісту поняття «Фінтех» (табл. 1). 


\begin{tabular}{|c|c|c|}
\hline \multicolumn{3}{|c|}{$\begin{array}{c}\text { Таблиця } 1 \\
\text { Визначення поняття «Фінтех» в зарубіжній і вітчизняній науковій літературі* }\end{array}$} \\
\hline $\begin{array}{l}\text { № } \\
\text { 3/II }\end{array}$ & Автор & Визначення \\
\hline \multicolumn{3}{|r|}{ Зарубіжні вчені } \\
\hline 1 & П. Геліс & $\begin{array}{l}\text { Фінтех - бізнеси нової, 4IR-хвилі, створені як відповідь на тотальну } \\
\text { цифровизацію економічних відносин, що представляють собою } \\
\text { самостійну альтернативу традиційним фінансовим бізнесам } \\
\text { (наприклад, банкам). }\end{array}$ \\
\hline 2 & А. Фітрі & $\begin{array}{l}\text { Фінтех - сукупність цифрових технологій, що використовуються в } \\
\text { фінансових транзакціях для підвищення їх ефективності на } \\
\text { фiнансовому ринку. }\end{array}$ \\
\hline 3 & П. Шуфель & $\begin{array}{l}\text { Фінтех - самостійний активатор фінансового ринку, орієнтований на } \\
\text { впровадження передових практик цифрових технологій в сферу } \\
\text { управління фінансовими активами. }\end{array}$ \\
\hline 4 & Дж. Ванг & $\begin{array}{l}\text { Фінтех - результат міжфірмової кооперації чистих фінансових } \\
\text { бізнесів і ІT, який об'єднує в собі фінансові необізнеси, побудовані } \\
\text { використанням кращих практик застосування цифрових технологій. }\end{array}$ \\
\hline 5 & Коваленко В.В. & $\begin{array}{l}\text { Сутність Фінтех - доцільно окреслити взаємозв’язком двох основних } \\
\text { компонент: інновацій, які засновані на технологіях традиційного } \\
\text { банківського сектору; та нових моделей надання фінансових послуг. }\end{array}$ \\
\hline 6 & $\begin{array}{l}\text { Мазаракі А., } \\
\text { Волосович С., } \\
\text { Д’яконова І., } \\
\text { Павленко Л., } \\
\text { Криклій О. }\end{array}$ & $\begin{array}{l}\text { Фінтех - це інноваційні технології, які використовуються } \\
\text { фінансовими інститутами, органами державного управління, } \\
\text { торговельними організаціями для задоволення потреб споживачів } \\
\text { фінансових, адміністративних послуг та товарів в умовах розвитку } \\
\text { економіки споживання. }\end{array}$ \\
\hline 7 & $\begin{array}{l}\text { Семеног А. Ю., } \\
\text { Цирулик С. В. }\end{array}$ & $\begin{array}{l}\text { Фінтех - це послуги, що надаються технологічними компаніями за } \\
\text { допомогою спеціального програмного забезпечення, та зосереджені } \\
\text { на задоволенні фінансових потреб клієнтів, пропонуючи зручні, } \\
\text { ефективні, автоматичні та прозорі он-лайн продукти порівняно } \\
\text { класичними фінансовими послугами. }\end{array}$ \\
\hline
\end{tabular}

\footnotetext{
*Складено на основі систематизації джерел $[1 ; 3 ; 6 ; 7]$
}

Спираючись на наукові судження зарубіжних і вітчизняних вчених, які вивчають питання формування Фінтех як гравців фінансового ринку і нової самостійної інституційної одиниці, варто виділити етапи формування Фінтех (табл.2).

Етапи становлення Фінтех як самостійного гравця фінансового ринку*

Таблиия 2

\begin{tabular}{|c|c|}
\hline Етап & Характеристика етапу становлення Фінтех \\
\hline $\begin{array}{l}\text { 1950-1960 pр. } \\
\text { Етап телевізійних } \\
\text { контактів }\end{array}$ & $\begin{array}{l}\text { Технологія реалізації відносин на фінансовому ринку: передача візуальної та } \\
\text { звукової інформації за допомогою телебачення. } \\
\text { Характеристика бізнес-моделі фінансового менеджменту: завдяки розвитку } \\
\text { телебачення формується новий інструмент реалізації управлінських впливів на } \\
\text { фінансовому ринку - контент аналіз ділових новин - тепер гравці отримують } \\
\text { додаткове перевага за умови доступу до телевізійних новин (ефект асиметричності } \\
\text { інформації). }\end{array}$ \\
\hline $\begin{array}{l}\text { 1967-1980 pp. } \\
\text { Етап } \\
\text { відеоконференцій }\end{array}$ & $\begin{array}{l}\text { Технологія реалізації відносин на фінансовому ринку: відеозв'язок / } \\
\text { відеоконференція. } \\
\text { Характеристика бізнес-моделі фінансового менеджменту: індивідуальні та групові } \\
\text { контакти власників капіталу і фінансових менеджерів через систему відеозв'язку як }\end{array}$ \\
\hline
\end{tabular}




\begin{tabular}{|l|l|}
\hline & в межах однієї країни, так і в міжнародному просторі. \\
\hline 31990 pр. - по & Технологія реалізації відносин на фінансовому ринку: комп'ютерна мережа Internet, \\
сьогодні & цифрових трансформацій \\
Етап Internet & Характеристика бізнес-моделі фінансового менеджменту: власник капіталу отримує \\
коммунікацій, & індивідуальний захищений доступ до фінансових активів та здатний приймати \\
цифрових & будь-які управлінські рішення, виходячи з наявної інформації. \\
трансформацій & \\
\hline
\end{tabular}

*Джерело [3]

В даний час глобальний ринок технологічних рішень для фінансової сфери є одним 3 найбільш швидкозростаючих у світі. Це означає, що проєкти, які вчора здавалися абсолютно фантастичними, вже сьогодні можуть перебувати в стадії фінального тестування або навіть бути запущені в експлуатацію. Ключові фактори, що впливають на розвиток індустрії Фінтех в сучасних умовах відображені в табл. 3.

Таблиця 3

Основні драйвери і бар'сри зростання Фінтех-індустрії в світі*

\begin{tabular}{|c|c|}
\hline Драйвери & Бар'єри \\
\hline $\begin{array}{l}\text { Наявність розвиненої } \text { цифрової } \\
\text { «традиційної» фінансової інфраструктури, на } \\
\text { базі якої легко реалізовувати інноваційні } \\
\text { проєкти. }\end{array}$ & $\begin{array}{l}\text { Нерозвинена або нерівномірно розвинена цифрова та } \\
\text { фінансова інфраструктура. }\end{array}$ \\
\hline $\begin{array}{l}\text { Високий інтерес інвесторів до інноваційних } \\
\text { Фінтех-проєктів. }\end{array}$ & Дефіцит кваліфікованих кадрів. \\
\hline $\begin{array}{l}\text { Наявність кваліфікованих і креативних кадрів } \\
\text { здатних генерувати нові рішення. }\end{array}$ & $\begin{array}{l}\text { Низький рівень технологічної та } \\
\text { грамотності населення. }\end{array}$ \\
\hline $\begin{array}{l}\text { Лояльність користувачів (фіз- та юрособи) до } \\
\text { «нетрадиційних» фінансових сервісів, } \\
\text { включаючи unbanked- i underbanked-сегменти. }\end{array}$ & $\begin{array}{l}\text { Низький рівень довіри населення до фінансових } \\
\text { технологій. }\end{array}$ \\
\hline \multirow[t]{3}{*}{$\begin{array}{l}\text { Ефективне державне регулювання, що сприяє } \\
\text { розвитку Фінтех-проєктів. }\end{array}$} & $\begin{array}{l}\text { Зростання кіберзагроз } \\
\text { кіберзлочиянцям. }\end{array}$ \\
\hline & $\begin{array}{l}\text { Недостатньо оперативне вдосконалення нормативно- } \\
\text { правового регулювання в сфері фінансових технології. }\end{array}$ \\
\hline & $\begin{array}{l}\text { Непрозорість ринків, внаслідок чого існують високі } \\
\text { ризики для локальних і зарубіжних інвесторів. }\end{array}$ \\
\hline
\end{tabular}

*Складено на основі систематизації джерел $[1 ; 4 ; 6 ; 8]$

Основними джерелами фінансування Фінтех-проєктів є венчурний капітал, угоди злиття i поглинання, а також прямі інвестиції. Тут варто зазначити, що у стартапів користуються популярністю альтернативні інструменти залучення фінансування: краудфандінг, краудінвестінг, P2В-кредитування, онлайн-факторинг. Але переважає саме венчурне фінансування. За оцінкою McKinsey, його частка в загальному обсязі фінансування становить понад 70\% [3]. В таблиці 4 відображені найбільші інвестиційні угоди Фінтех в 2020 році.

Що стосується українського ринку Фінтеху, то за даними UAFIC налічується понад 100 фінтехкомпаній, переважна більшість 3 яких - провайдери платіжних сервісів, також розвинено онлайнкредитування та інфраструктурні рішення. 
Найбільші інвестиційні угоди в сфері Фінтех в 2020 р*.

\begin{tabular}{|c|c|c|c|c|c|}
\hline № & $\begin{array}{c}\text { Назва } \\
\text { стартапу }\end{array}$ & $\begin{array}{c}\text { Напрямок } \\
\text { діяльності }\end{array}$ & Країна & $\begin{array}{c}\text { Вартість } \\
\text { угоди, } \\
\text { млрд. дол. } \\
\text { США }\end{array}$ & Механізм \\
\hline 1 & Refinitiv & $\begin{array}{c}\text { Корпоративний } \\
\text { напрямок }\end{array}$ & США & 17,0 & $\begin{array}{c}\text { викуп компанії } \\
\text { інвесторами }\end{array}$ \\
\hline 2 & Ant Financial & $\begin{array}{c}\text { Платіжні } \\
\text { транзакції }\end{array}$ & Китай & 14,0 & $\begin{array}{c}\text { випуск цінних } \\
\text { паперів серії C }\end{array}$ \\
\hline 3 & Worldpay & $\begin{array}{c}\text { Платіжні } \\
\text { транзакції }\end{array}$ & Великобританія & 12,9 & М \& А-угода \\
\hline 4 & Nets & $\begin{array}{c}\text { Платіжні } \\
\text { транзакції }\end{array}$ & Данія & 5,5 & $\begin{array}{c}\text { викуп компанії } \\
\text { інвесторами }\end{array}$ \\
\hline 5 & Blackhawk & $\begin{array}{c}\text { Платіжні } \\
\text { транзакції }\end{array}$ & Канада & 3,5 & $\begin{array}{c}\text { викуп компанії } \\
\text { інвесторами }\end{array}$ \\
\hline 6 & Verwork & $\begin{array}{c}\text { Платіжні } \\
\text { транзакції }\end{array}$ & США & 3,4 & $\begin{array}{c}\text { викуп компанії } \\
\text { інвесторами }\end{array}$ \\
\hline 7 & ПZеttle & $\begin{array}{c}\text { Платіжні } \\
\text { транзакції }\end{array}$ & Швеція & 2,2 & М \& А-угода \\
\hline
\end{tabular}

*Складено на основі систематизації джерел $[1 ; 3 ; 6 ; 7]$

Рівень розвитку глобальних напрямів Фінтех в Україні (кількість компаній) показано на рис.1.

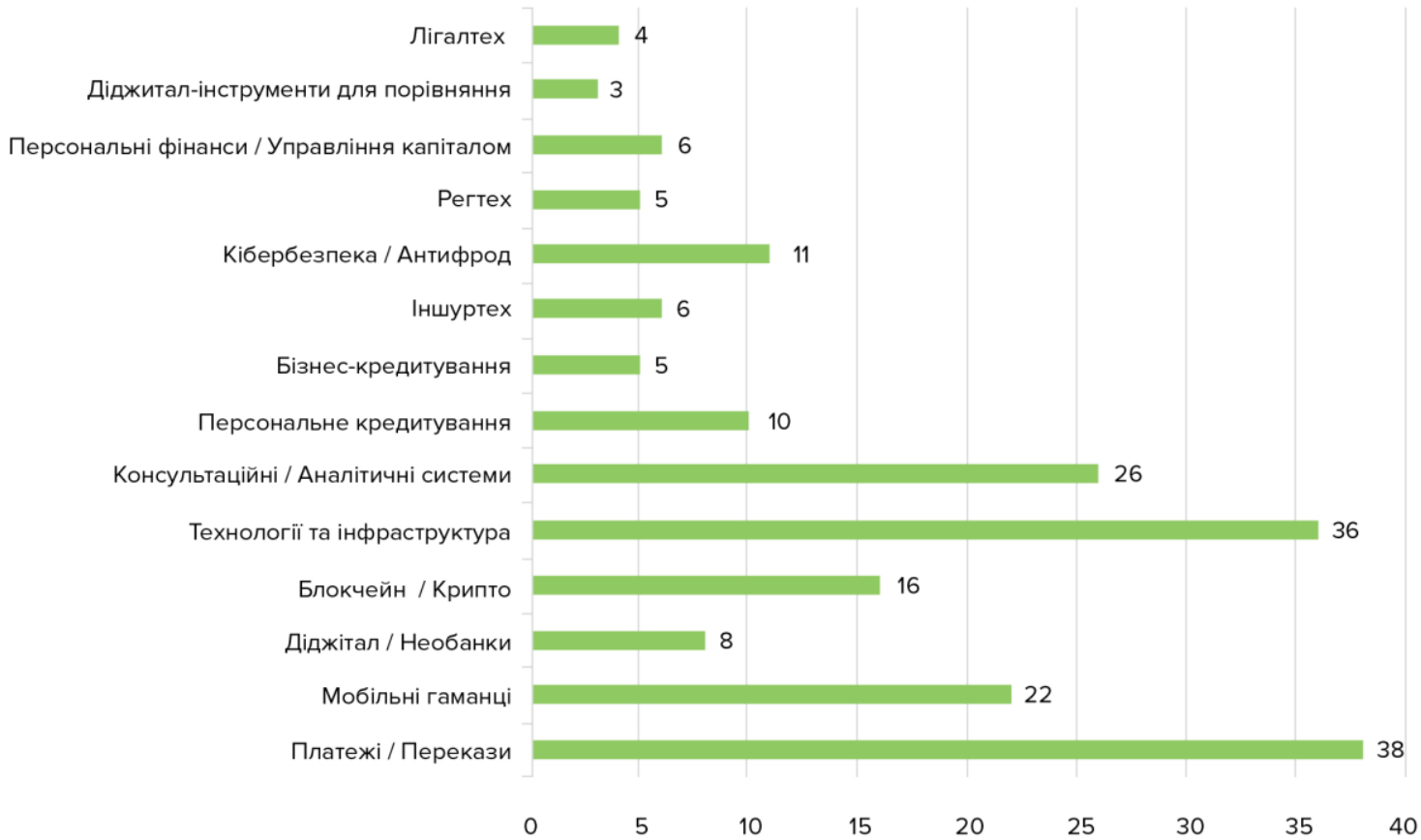

Рис.1. Глобальні напрями Фінтех в Україні*

*Джерело [7]

Виходячи з глобальних напрямів Фінтех в Україні перейдемо до розгляду практики організації Фінтех в світових країнах - лідерах розвитку фінансового ринку - ЄС, США і Китаї (табл. 5).

У США і ЄС розвиток Фінтех має більш виражену комерційну складову: по-перше, наявність вільних капіталів визначило необхідність формування нової ніші для інвестицій, по-друге, в зазначених країнах фінансовий ринок тяжіє до продуктової і сервісної сегментації, і Фінтех $€$ 
драйвером для створення вузьких нішевих продуктів та сервісів переважно для роздрібних клієнтів; по-третє, Фінтех в зазначених країнах, незважаючи на його включення в програми пріоритетного технологічного розвитку, зберігає статус відособленості, а традиційними гравцями фінансового ринку і зовсім розглядається як реальний конкурент, і набагато рідше - як партнер.

Таблиия 5

Характеристика організації Фінтех в світових країнах - лідерах розвитку фінансового

\begin{tabular}{|c|c|c|c|}
\hline \multicolumn{4}{|c|}{ ринку * } \\
\hline $\begin{array}{c}\text { Критерії } \\
\text { порівняння } \\
\end{array}$ & EC & США & Китай \\
\hline $\begin{array}{l}\text { 1. Фактори } \\
\text { драйвери } \\
\text { розвитку } \\
\text { Фінтех }\end{array}$ & $\begin{array}{l}\text { - підвищення прозорості } \\
\text { та стабільності } \\
\text { наднаціонального } \\
\text { фінансового ринку; } \\
\text {-уніфікація стандартів } \\
\text { кібербезпеки в фінансових } \\
\text { операціях; } \\
\text { - формування єдиного } \\
\text { інформаційного простору } \\
\text { для діяльності банків }\end{array}$ & $\begin{array}{l}\text { - політична зацікавленість } \\
\text { в отриманні нових } \\
\text { інструментів впливу на } \\
\text { фінансовому ринку; } \\
\text { - інтеграція мегабізнесів } \\
\text { FAMGA на фінансовому } \\
\text { ринку }\end{array}$ & \begin{tabular}{lr}
- & \multicolumn{2}{c}{ економічний } \\
iнфраструктурний & розвиток \\
регіонів; & \\
-підвищення & прозорості та \\
ефективності & фінансової \\
системи; & -розвиток \\
національних & інвестиційни \\
та ощадних & програм для \\
населення &
\end{tabular} \\
\hline $\begin{array}{l}\text { 2. Ключові } \\
\text { гравці } \\
\text { формування } \\
\text { Фінтех }\end{array}$ & $\begin{array}{l}\text {-Загальноєвропейський } \\
\text { регулятор ринків ESMA; } \\
\text {-Європейський } \\
\text { Центральний банк }\end{array}$ & $\begin{array}{l}\text { - органи регулювання } \\
\text { фінансового ринку (Бюро } \\
\text { фінансового захисту } \\
\text { споживачів, Комісія } 3 \\
\text { цінних паперів і капіталу, } \\
\text { Агентство по боротьбі } 3 \\
\text { фінансовими злочинами); } \\
\text { - фінансові холдинги (JP } \\
\text { Morgan Chase; Bank of } \\
\text { America) }\end{array}$ & $\begin{array}{lr}\text {-державні органи } & \text { управління } \\
\text { фінансовим } & \text { ринком } \\
\text { (Народний } & \text { банк Кита; } \\
\text { Комісія } & \text { регулювання } \\
\text { банківської } & \text { діяльності } \\
\text { страхування; } & \text { Комісія } \\
\text { регулювання цінних паперів); } \\
\text { - дочірні структури групи ВА }\end{array}$ \\
\hline $\begin{array}{l}\text { 3. Джерела } \\
\text { фінансування } \\
\text { розвитку } \\
\text { Фінтех }\end{array}$ & $\begin{array}{lr}\text { - союзний } & \text { венчурний } \\
\text { фонд Horizon } & \text { Europe, } \\
\text { SoftBank Vision } & \text { Fund i } \\
\text { Clermont Group; } & \\
\text { - міждержавні } & \text { програми } \\
\text { розвитку } & \text { Фінтех, } \\
\text { ініційовані } & \text { банками } \\
\text { (наприклад, } & \\
\text { Великобританія- } & \\
\text { Швейцарія; Нідерланди - } \\
\text { Німеччина - Франція) }\end{array}$ & $\begin{array}{l}\text { - приватні програми } \\
\text { розвитку Фінтех групи } \\
\text { FAMGA; } \\
\text {-банківські інвестиції в } \\
\text { Фінтех в обмін на права } \\
\text { керування бізнесом; } \\
\text { - S \& P- фондування } \\
\text { венчурних } \\
\text { банків і IT-компаній) }\end{array}$ & 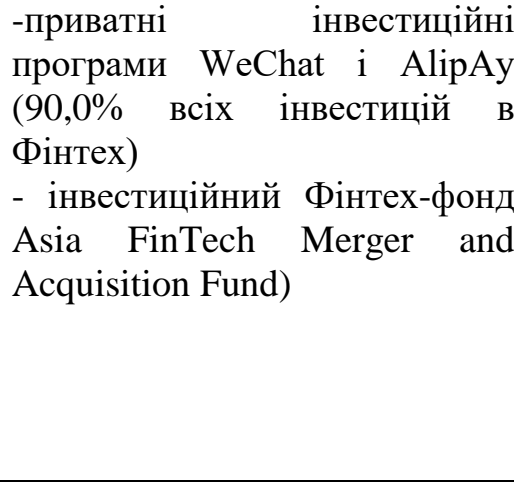 \\
\hline
\end{tabular}

* Складено на основі систематизації джерел [2; 6; 7]

Для Китаю Фінтех є дуалістичним щаблем розвитку фінансового ринку: так, з одного боку, Фінтех $\epsilon$ інструментом інфраструктурного та сервісного розвитку регіонів за рахунок приватних інвестицій IT-гігантів групи BAT (WeChat i AlipAy зобов'язані розвивати цифрові технології в регіоні, а також сприяти економічному розвитку територій своєї присутності), з іншого боку, Фінтехрішення групи ВАТ не тільки сприяють розвитку національного фінансового ринку країни, але також підвищують фінансову культуру населення $\mathrm{i}$, про що зазвичай не відзначається відкрито, $\epsilon$ джерелами даних про громадян Китаю, їх споживчій поведінці, доходах i інший приватній інформації, яка збирається, і аналізується власниками сервісів, а потім передається відповідним державним органам контролю. 
Водночас у Китаї фінансування Фінтех переважно зосереджено в руках мегабізнесів групи ВАТ, яка практично повністю веде Фінтех, а від держави отримує податкові пільги та інші преференції, наприклад, по лінії митних платежів або адміністративно-регулятивних процедур; крім цього, в Китаї діє спеціалізований інвестиційний фонд - Asia FinTech Merger and Acquisition Fund, що відповідає за експертний відбір і фінансування перспективних Фінтех-проєктів [7].

Водночас слід розуміти, що Фінтех, несучи в собі позитиви для фінансового ринку, значно збільшує виклики і загрози його стабільного й безпечного функціонування, що обумовлено наступними причинами [6, с.185]:

1) для ефективного функціонування Фінтех необхідні персональні дані про клієнтів i ïx фінансових транзакціях, які збираються за допомогою механізму Big Data i стандарту відкритих банківських даних АРI;

2) Фінтех-сервіси прагнуть до міжпродуктової кооперації, саме так вони можуть більш якісно задовольняти запити клієнтів, тобто виникає необхідність передачі персональних даних, а іноді й фінансових активів між різними продуктами Фінтех;

3) в даний час в сфері Фінтех немає єдиного стандарту безпеки обміну даними, і кожен Фінтехгравець визначає для себе власні правила кіберзахисту інформації;

4) фінансові технології є одним з найбільш популярних об'єктів для кібератак і хакінгу з метою розкрадання персональної інформації, фінансових активів або здійснення шахрайських операцій від імені клієнта.

Виходячи 3 означених вище причин формування Фінтех-сервісами викликів i загроз для фінансового ринку, розглянемо найбільш актуальні для вітчизняної дійсності виклики і загрози розвитку Фінтех (табл. 6).

Табличя 6

\section{Основні виклики і загрози для вітчизняного фінансового ринку, які генеруються} розвитком Фінтех*

\begin{tabular}{|c|c|c|}
\hline 1. & $\begin{array}{l}\text { Формування фінансових } \\
\text { бульбашок в сфері } \\
\text { мікрокредитування } \\
\text { Р2Р-позик }\end{array}$ & $\begin{array}{l}\text { Фінтех-сервіси в сфері мікрокредитування і Р2Р-позик використовують } \\
\text { більш гнучкий і лояльний алгоритм скорингу, і тестування } \\
\text { кредитоспроможності клієнта та є альтернативним інструментом } \\
\text { отримання кредиту для клієнтів з негативною кредитною історією або } \\
\text { вже мають проблемні борги перед банком. }\end{array}$ \\
\hline 2. & $\begin{array}{l}\text { Неправомірне } \\
\text { використання особистої } \\
\text { інформації про клієнтів } \\
\text { в комерційних цілях }\end{array}$ & $\begin{array}{l}\text { Функціонування Фінтех засноване на аналізі персональної інформації } \\
\text { про клієнта, і вона ж є своєрідним гарантом безпеки при здійсненні } \\
\text { фінансових транзакцій, однак при відсутності належної регуляції, такі } \\
\text { компанії можуть використовувати персональні дані як інструмент } \\
\text { шантажу, тиску або комерційного об'єкта для передачі третім особам, } \\
\text { які не беруть участь у фінансових відносинах. }\end{array}$ \\
\hline 3. & $\begin{array}{lr}\text { Ризики запровадження в } \\
\text { оману користувача щодо } \\
\text { провайдера } \\
\text { (включаючи } \\
\text { анонімності } \\
\text { послугайдера } \\
\text { послуг) }\end{array}$ & $\begin{array}{l}\text { Фінтех-сервіси функціонують переважно на інфраструктурі телеком- } \\
\text { провайдерів і в разі виникнення форс-мажорних обставин визначення } \\
\text { міри відповідальності учасників здійснення фінансових транзакцій } \\
\text { проблематично. Крім цьог, Фінтех-компанія і телеком-оператор } \\
\text { можуть вступити в злочинну змову } 3 \text { метою збагачення за рахунок } \\
\text { операцій клієнтів. }\end{array}$ \\
\hline 4. & $\begin{array}{l}\text { Використання Фінтех- } \\
\text { сервісів у відмиванні } \\
\text { грошей i фінансування } \\
\text { тероризму }\end{array}$ & $\begin{array}{l}\text { Фінтех-сервіси багато в чому } є \\
\text { проведення фінструментами для анонімного } \\
\text { електронні гаманці), крім цього Фінтех переважно розвивається як } \\
\text { інфраструктура для грошових переказів в обхід банків - все це несе в } \\
\text { собі ризики здійснення грошових переказів для приховування доходів } \\
\text { від податкових органів та фінансування забороненої діяльності. }\end{array}$ \\
\hline 5 & $\begin{array}{lrr}\text { Загроза } & \text { інтервенції } \\
\text { зовнішнього } & \text { впливу на } \\
\text { фінансовий } & \text { ринок }\end{array}$ & $\begin{array}{l}\text { Присутність на національному фінансовому ринку іноземних } \\
\text { фінтехекосистем (група FAMGA, BAT, Ant Financial i ïх продукти) } є \\
\text { прикладом інтервенції в фінансову систему, а значить, несуть в собі }\end{array}$ \\
\hline
\end{tabular}




\begin{tabular}{|l|l|l|c|}
\hline \hline & іноземними \\
маркетплейсами & $\begin{array}{l}\text { ризики зміни конкурентного ландшафту i монополізації окремих } \\
\text { сегментів ринку за рахунок опори на міжнародно визнане } \\
\text { iнфраструктурне забезпечення (наприклад, партнерство } 3 \text { платіжними } \\
\text { системами Visa, Mastercard i т.п.). }\end{array}$ \\
\hline
\end{tabular}

*Складено на основі систематизації джерел $[3 ; 6 ; 8]$

Поряд із певними загрозами, вплив новітніх технологій на сучасний фінансовий ринок сьогодні дуже складно переоцінити. Фінтех - це та індустрія, яка бурхливо та невпинно розвивається, проникає в усі сфери фінансової діяльності та демонструє клієнтам нові й зручні фінансові сервіси та інструменти. Завдяки цьому сучасний споживач кардинально змінює своє ставлення до фінансових послуг. Він прагне дистанційності, легкості та безпеки в управлінні власними фінансами. У цій синергії народжується майбутнє фінансового сектору - і світового, і вітчизняного. I це майбутнє нерозривно пов'язане з розвитком Фінтех.

Висновки i перспективи подальших досліджень. За результатами дослідження було встановлено, що Фінтех є важливою ідеологією ведення бізнесу на фінансовому ринку. В сучасних умовах Фінтех може бути визначений, з одного боку, як набір технологій, який використовується учасниками фінансового ринку для підвищення ефективності операцій з фінансовими активами, 3 іншого боку - це новітній інституційний гравець, який об'єднує найбільш технологічно просунуті фінансові бізнеси - прямі конкуренти традиційним учасникам фінансового ринку.

При цьому ключовими учасниками є переважно технологічні компанії, а не традиційні гравці фінансового сектора. Фінтех-проєкти оперативніше класичних фінансових організацій інтегрують інновації, швидше додають нові продукти і сервіси, змінюють бізнес-моделі і готові надавати послуги практично у всіх ринкових сегментах. Традиційні ж учасники змушені пристосовуватися до нових реалій і адаптувати власні продукти або розробляти нові. Сьогодні зростає конкуренція між технологічними компаніями та фінансовими організаціями. Піонерами Фінтех вважаються американські технологічні компанії. Велика кількість інноваційних проєктів, розроблених переважно в Силіконовій долині, сприяла створенню сприятливого середовища для розвитку нової галузі. Однак сьогодні центрами фінансових технологій стають й і інші країни, наприклад, Великобританія, Сінгапур, Південна Корея та інші.

Безумовно основними факторами, що активно стимулюють розвиток сектора фінансових технологій, стали зростання проникнення інтернету в усьому світі, а також процеси цифровізації, що охопили практично всі сфери людського життя, включаючи і фінансовий сектор.

\section{Джерела та література}

1. Васильєва Т. А., Лєонов С. В., Рубанов П. М. Трансформація обігових фінансових інструментів в умовах цифровізації фінансового сектору економіки. Вісник Сумського державного університету. Серія Економіка. 2017. № 3. С. 15-21.

2. Карлін М. І. Фінансові офшори : навч. посіб. для студ. ВНЗ III-IV рівнів акредитації. М. I. Карлін, О. В. Борисюк. Луцьк : Вежа-Друк, 2016. 240 с.

3. Паперник C. Fintech - актуальні тенденції на найближчі 3 роки. Юридична газета. 2018. URL: http://evris.law/uk/stattja-fintech.

4. Поченчук Г. М. Фінансові технології: розвиток і регулювання. Економіка і суспільство. 2017. № 13. С. 193-200.

5. Рубанов П. М. Аналіз сутності FinТесh інновацій. Вісник ХНУ. 2019. №4. Том 2. С. 73-76.

6. Рубанов П. М. Структура ринку FinTech інновацій. Науковий вісник Полісся. 2019. № 2 (18). С. 184189.

7. Стратегія розвитку фінтеху в Україні до 2025 року. Національний банк України. URL: https://bank.gov.ua/ua/about/developstrategy/fintech2025.

8. Язлюк Б. О., Гевко Р. Б., Дзядикевич Ю. В. Теоретичні та прикладні аспекти економічної безпеки України. Інновачійна економіка. 2015. № 4. С. 310-315. 


\section{References}

1. Vasylieva T. A., Lieonov S. V., Rubanov P. M. (2017). Transformatsiia obihovykh finansovykh instrumentiv $\mathrm{v}$ umovakh tsyfrovizatsii finansovoho sektoru ekonomiky. [Transformation of circulating financial instruments in the conditions of digitalization of the financial sector of the economy]. Visnyk Sumskoho derzhavnoho universytetu. Seriia Ekonomika. Vol 3. PP. 15-21. [in Ukrainian].

2. Karlin M. I. Borysjuk O.V.(2016). Finansovi ofshory. [Financial offshore]. Lucjk : Vezha-Druk, 240 pp. [in Ukrainian].

3. Papernyk S. (2018). Fintech - aktualni tendentsii na naiblyzhchi 3 roky. Yurydychna [Fintech - current trends for the next 3 years.]. Yurydychna hazeta. URL: http://evris.law/uk/stattja-fintech. [in Ukrainian].

4. Pochenchuk H. M. (2017). Finansovi tekhnolohii: rozvytok i rehuliuvannia. [Financial technologies: development and regulation]. Ekonomika i suspilstvo. Vol 13. PP. 193-200. [in Ukrainian].

5. Rubanov P. M. (2019). Analiz sutnosti FinTech innovatsii. [Analysis of the essence of FinTech innovations.]. Visnyk KhNU. Vol 13. PP. 1193-1200. [in Ukrainian].

6. Rubanov P. M. (2019). Struktura rynku FinTech innovatsii. [FinTech innovation market structure.] Naukovyi visnyk Polissia. Vol 2 (18). PP. 184-189. [in Ukrainian].

7. Stratehiia rozvytku fintekhu v Ukraini do 2025 roku. Natsionalnyi bank Ukrainy. URL: https://bank.gov.ua/ua/about/developstrategy/fintech2025.

8. Yazliuk B. O., Hevko R. B., Dziadykevych Yu. V. (2015). Teoretychni ta prykladni aspekty ekonomichnoi bezpeky Ukrainy. [Theoretical and applied aspects of economic security of Ukraine. Innovatsiina ekonomika. Vol 4. PP. 310-315. [in Ukrainian]. 